УДК 349.3

DOI https://doi.org/10.32849/2663-5313/2020.2.21

\title{
Ольга Бурлака,
}

докт. юрид.наук, дочент,

професор кафедри чивільного права і прочесу

Національної академії внутрішніх справ

\section{СУЧАСНИЙ СТАН ПРАВОВОГО РЕГУЛЮВАННЯ СОЦІАЛЬНОГО ЗАХИСТУ СІМ'Ї, ДИТИНСТВА, МАТЕРИНСТВА ТА БАТЬКІВСТВА В УКРАЇНI}

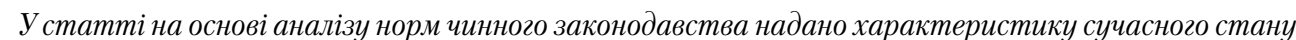
правового регулювання соціального захисту сім'ї, дитинства, материнства та батьківства в Україні. Визначено проблеми нормативного забезпечення окресленої сфери. Запропоновано систематизувати чинне законодавство у сфері соціального захисту сім'ї, дитинства, материнства та батьківства та прийняти єдиний нормативно-правовий акт, який би регулював дане питання. Визначено, що одним з основних нормативно-правових актів у сфері сочіального захисту як усього населення, так $і$ сімей з дітьми, багатодітних, неповних та малозабезпечених сімей, дітей-сиріт та дітей, позбавлених батьківського піклування, інвалідів з дитинства та дітей-інвалідів є Закон Украӥни «Про державні соціальні стандарти та державні сочіальні гарантії», який встановлює найважливіші державні сочіальні стандарти і нормативи у різних сферах життєдіяльності. Наголошено, що державна иільова підтримка для здобуття вищої освіти полягає у: повній або частковій оплаті навчання за рахунок коштів державного та місиевих бюджетів; пільгових довгострокових кредитах для здобуття освіти; сочіальній стипендіі; безоплатному забезпеченні підручниками; безоплатному доступі до мере жі Інтернет, систем баз даних у державних та комунальних навчальних закладах; безоплатному проживанні в гуртожитку тощо. Зроблено висновок, що на нормативному рівні існує певна невпорядкованість відповідних видів соиіального захисту сім'ї, дитинства, материнства та батьківства, оскільки норми, які визначають допомоги, послуги і пільги для сімей з дітьми, багатодітних, неповних та малозабезпечених сімей, дітей-сиріт та дітей, позбавлених батьківського піклування, інвалідів з дитинства та дітей-інвалідів та встановлюють сочіальні гарантії реалізації іхнього права на соціальний захист, розосереджені в багатьох підзаконних нормативно-правових актах, що ускладнює застосування їх на практииі, а також призводить до незнання громадянами своїх соиіальних прав. У зв'язку з иим запропоновано систематизувати чинне законодавство у сфері соціального захисту сім'̈̈, дитинства, материнства та батьківства та прийняти єдиний нормативно-правовий акт, який би регулював дане питання.

Ключові слова: правове регулювання, соціальний захист сім'ї, дитинство, материнство, батьківство, законодавство.

Постановка проблеми. Стратегічна мета сучасної цивілізаційної держави полягає в провадженні ефективної соціальної політики, спрямованої на забезпечення належного матеріального становища її громадян. Розвиток держави є відображенням соціальної структури суспільства, а показником якісної соціальної політики є реалізація державних соціальних стандартів та гарантій, що вказують на політику держави загалом [1, с. 102]. Для досягнення вказаної мети необхідно запровадити ефективне правове регулювання соціального захисту як усього населення, так і сім'ї, дитинства, материнства та батьківства. Слушною вважаємо думку С. С. Алексєєва, який серед особливостей правового регулювання суспільних відносин визначає насамперед те, що воно, відповідно до своєї соціальної природи, є таким різновидом соціального регулювання, який має цілеспрямований, організований за своєю націленістю, результативний характер. Окрім того, правове регулювання здійснюється за допомогою цілісної системи засобів, які реально виражають саму матерію права як нормативного інституційного утворення регулятора [2, с. 145-150]. Особливість правового регулювання також полягає в тому, що воно має свій специфічний механізм, під яким розуміють взяту у єдності систему правових засобів, за допомогою яких забезпечується результативний правовий вплив на суспільні відносини [3, с. 211; 4].

Стан дослідження. Окремі проблемні питання правового регулювання соціального захисту сім'ї, дитинства, материнства та бать- 
ківства в Україні у своїх наукових працях розглядали: В. М. Андріїв, В. С. Андрєєв, А. Г. Бірюкова, С. Я. Вавженчук, В. С. Венедіктов, С. В. Венедіктов, В. Д. Гетьманцева, Ю. М. Гришина, Т. А. Занфірова, О. Л. Кучма В. В. Лаврухін, Н. О. Мельничук, О. В. Москаленко, В. І. Надрага, О. М. Потопахіна В. I. Прокопенко, В. І. Щербина, С. П. Яригіна, О. М. Ярошенко та інші. Проте, незважаючи на значний науковий доробок з даної проблематики, комплексні дослідження соціального захисту таких вразливих верств населення, як сім'ї з дітьми, багатодітні, неповні та малозабезпечені сім'ї, діти-сироти та діти, позбавлені батьківського піклування, інваліди з дитинства та діти-інваліди, практично відсутні, тому багато питань у цій сфері потребують подальшого дослідження.

Саме тому мета статті - надати оцінку сучасному стану правового регулювання соціального захисту сім'ї, дитинства, материнства та батьківства в Україні.

Виклад основного матеріалу. Правове регулювання соціального захисту сім'ї, дитинства, материнства та батьківства в Україні здійснюється за допомогою міжнародних норм і норм національного законодавства. Так, основними положеннями є норми Конституції України, в ст. 46 якої визначаються основні засади, а саме передбачено право громадян на соціальний захист, а ст. 52 Конституції проголошує, що діти рівні у своїх правах незалежно від походження, а також від того, народжені вони у шлюбі чи поза ним. Будь-яке насильство над дитиною та її експлуатація переслідуються за законом. Утримання та виховання дітей-сиріт і дітей, позбавлених батьківського піклування, покладається на державу. Держава заохочує і підтримує благодійницьку діяльність щодо дітей [5]. Тобто діти, незалежно від того, чи вони живуть у сім'ї, чи вони позбавлені батьківського піклування і виховуються у відповідних дитячих закладах, мають право на належні умови життя, дбайливе ставлення до себе, право на забезпечення можливості розвиватися духовно, фізично, морально, інтелектуально.

Наступним нормативно-правовим актом, який $€$ частиною системи національного законодавства у сфері соціального захисту сім'ї, дитинства, материнства та батьківства, є Сімейний кодекс України, в якому визначено важливість сім'ї як первинного та основного осередку суспільства, що підлягає державній охороні. Так, ст. 5 Кодексу регламентує, що держава охороняє сім'ю, дитинство, материнство, батьківство, створює умови для зміцнення сім'ї. Держава створює людині умови для материнства та батьківства, забезпечує охорону прав матері та батька, матеріально і морально заохочуе і підтримує материнство та батьківство. Держава забезпечує пріоритет сімейного виховання дитини. Держава бере під свою охорону кожну дитину-сироту i дитину, позбавлену батьківського піклування [6]. Також у Сімейному кодексі визначені положення, які передбачають порядок і особливості влаштування дітей-сиріт, дітей, позбавлених батьківського піклування, шляхом усиновлення, встановлення над такою дитиною опіки чи піклування, здійснення патронату над дітьми, влаштування дітей до прийомної сім'ї, дитячого будинку сімейного типу.

Закони України «Про освіту», «Про вищу освіту» визначають певні гарантії у сфері освіти для дітей-сиріт, дітей, позбавлених батьківського піклування, та встановлюють пільги щодо прийому на навчання до вищих навчальних закладів для окремих категорій дітей, щоб такі діти мали змогу повною мірою реалізувати своє конституційне право на освіту, в рамках якого здобути відповідну спеціальність та професію.

Для реалізації такого права у ст. 37 Закону України «Про освіту» закріплено необхідність у створенні навчальних закладів для громадян, які потребують соціальної допомоги та реабілітації. У цій статті йдеться про таке: для дітей, які не мають необхідних умов для виховання і навчання в сім'ї, створюються загальноосвітні школи-інтернати. Для дітей-сиріт і дітей, які залишилися без піклування батьків, створюються школи-інтернати, дитячі будинки, в тому числі сімейного типу, з повним державним утриманням. Для дітей, які потребують тривалого лікування, створюються дошкільні навчальні заклади, загальноосвітні санаторні школи-інтернати, дитячі будинки. Навчальні заняття з такими дітьми проводяться також у лікарнях, санаторіях, вдома. Для осіб, які мають вади у фізичному чи розумовому розвитку і не можуть навчатися в масових навчальних закладах, створюються спеціальні загальноосвітні школи-інтернати, школи, дитячі будинки, дошкільні та інші навчальні заклади з утриманням за рахунок держави. Для дітей і підлітків, які потребують особливих умов виховання, створюються загальноосвітні школи і професійно-технічні училища соціальної реабілітації.

Порядок забезпечення учнів державних та комунальних професійно-технічних навчальних закладів стипендією, організації харчування учнів із числа дітей-сиріт, дітей, позбавлених батьківського піклування, осіб 3 їх числа, дітей-інвалідів/інвалідів 
I-III групи та дітей із сімей, які отримують допомогу відповідно до Закону України «Про державну соціальну допомогу малозабезпеченим сім'ям», визначається Кабінетом Міністрів України [7]. Таким чином, держава намагається забезпечити всі належні умови для виховання дітей-сиріт, дітей, позбавлених батьківського піклування, і дітей, які потребують особливих умов виховання, їх розвитку з метою адаптації таких дітей до умов соціального середовища.

Також в абзаці 2 ч. 3 статті 44 Закону України «Про вищу освіту» визначено, що брати участь у конкурсі за результатами вступних іспитів з конкурсних предметів у вищому навчальному закладі у межах установлених квот прийому до вищих навчальних закладів (наукових установ) України мають право особи (за їхнім вибором), які мають захворювання, що можуть бути перешкодою для проходження зовнішнього незалежного оцінювання, діти-сироти та особи, яких законом визнано учасниками бойових дій та які захищали незалежність, суверенітет і територіальну цілісність України, брали участь в антитерористичній операції, забезпеченні її проведення.

Частина 17 ст. 44 закону передбачає обов'язок держави щодо забезпечення особам, визнаним учасниками бойових дій, та їнім дітям, дітям, один із батьків яких загинув (пропав безвісти) у районі проведення антитерористичних операцій, бойових дій чи збройних конфліктів або помер внаслідок поранення, контузії чи каліцтва, одержаних у районі проведення антитерористичних операцій, бойових дій чи збройних конфліктів, а також внаслідок захворювання, одержаного в період участі в антитерористичній операції, дітям, один із батьків яких загинув під час масових акцій громадянського протесту або помер внаслідок поранення, контузії чи каліцтва, одержаних під час масових акцій громадянського протесту, дітям, зареєстрованим як внутрішньо переміщені особи, у тому числі дітям, які навчаються за денною формою навчання у вищих навчальних закладах, до закінчення навчальних закладів, але не довше ніж до досягнення ними 23 років, державну цільову підтримку для здобуття вищої освіти у державних та комунальних навчальних закладах.

Відповідна державна цільова підтримка для здобуття вищої освіти полягає у: 1) повній або частковій оплаті навчання за рахунок коштів державного та місцевих бюджетів; 2) пільгових довгострокових кредитах для здобуття освіти; 3) соціальній стипендії; 4) безоплатному забезпеченні підручниками; 5) безоплатному доступі до мережі Інтернет, систем баз даних у державних та комунальних навчальних закладах; 6) безоплатному проживанні в гуртожитку; тощо [8]. Така державна цільова підтримка спрямована на підвищення добробуту дітей, поліпшення їх якості життя, подолання соціального відторгнення таких дітей та забезпечення реалізації основоположного принципу рівності прав усіх громадян.

Закон України «Про безоплатну правову допомогу» [9] також містить відповідні пільги щодо надання відповідним категоріям громадян безоплатної вторинної правової допомоги, а саме: 1) дітям-сиротам, дітям, позбавленим батьківського піклування, дітям, які перебувають у складних життєвих обставинах, дітям, які постраждали внаслідок воєнних дій та збройних конфліктів; 2) особам, які перебувають під юрисдикцією України, якщо середньомісячний сукупний дохід їхньої сім'ї нижчий від суми прожиткового мінімуму, розрахованого та затвердженого відповідно до Закону України «Про прожитковий мінімум» для осіб, які належать до основних соціальних і демографічних груп населення, інвалідам, які отримують пенсію або допомогу, що призначається замість пенсії, у розмірі, меншому за два прожиткових мінімуми для непрацездатних осіб, на всі види правових послуг; захист; здійснення представництва інтересів таких дітей в судах, інших державних органах, органах місцевого самоврядування, перед іншими особами; складення документів процесуального характеру.

Наступним одним із основних нормативно-правових актів у сфері соціального захисту як усього населення, так і сімей 3 дітьми, багатодітних, неповних та малозабезпечених сімей, дітей-сиріт та дітей, позбавлених батьківського піклування, інвалідів 3 дитинства та дітей-інвалідів $€$ Закон України «Про державні соціальні стандарти та державні соціальні гарантії» [10], який встановлює найважливіші державні соціальні стандарти і нормативи у різних сферах життєдіяльності: у сфері житлово-комунального обслуговування, у сфері транспортного обслуговування та зв'язку, у сфері охорони здоров'я, у сфері забезпечення навчальними закладами, у сфері обслуговування закладами фізичної культури та спорту, у сфері побутового обслуговування, торгівлі та громадського харчування; визначає основні державні соціальні гарантії (мінімальний розмір заробітної плати, мінімальний розмір пенсії за віком, неоподатковуваний мінімум доходів громадян, розміри державної соціаль- 
ної допомоги та інших соціальних виплат), порядок визначення і іх розмір; джерела і способи забезпечення їх фінансування.

У Законі України «Про охорону дитинства» [11] визначено, що кожна дитина має право на рівень життя, достатній для її фізичного, інтелектуального, морального, культурного, духовного і соціального розвитку. Також для забезпечення належного рівня життя дітей та належних матеріальних умов для їх виховання у ст. 13 вказаного закону встановлено обов'язок держави надавати соціальну допомогу батькам або особам, які їх замінюють. Порядок та особливості надання такої допомоги визначаються Законом України від 21.11.1992 № 2811-XII «Про державну допомогу сім'ям 3 дітьми» [12], де у ст. 3 цього закону передбачено, що до державної допомоги сім'ям 3 дітьми належать: 1) допомога у зв'язку з вагітністю та пологами; 2) допомога при народженні дитини; 3) допомога при усиновленні дитини; 4) допомога на дітей, над якими встановлено опіку чи піклування; 5) допомога на дітей одиноким матерям.

Необхідно зауважити, що у зв'язку 3 нестабільною політичною та економічною ситуацією в Україні, подорожчанням послуг і товарів, масовим звільненням працівників значна частина сімей з дітьми $€$ малозабезпеченими i підпадають під дію Закону України «Про державну соціальну допомогу малозабезпеченим сім'ям» від 01.06.2000 № 1768-III [13]. Відповідний закон визначає, що малозабезпеченою є сім'я, яка з поважних або незалежних від неї причин має середньомісячний сукупний дохід, нижчий від прожиткового мінімуму для сім'ї. Такі сім'ї мають право на отримання щомісячної допомоги у грошовій формі в розмірі, що залежить від величини середньомісячного сукупного доходу сім'ї. Порядок надання допомоги малозабезпеченим сім'ям передбачений Постановою Кабінету Міністрів України від 24 лютого 2003 р. № 250 «Про затвердження Порядку призначення і виплати державної соціальної допомоги малозабезпеченим сім'ям».

Основні засади, заходи соціального захисту дітей-сиріт та дітей, позбавлених батьківського піклування, а також осіб із їх числа та державні соціальні стандарти і нормативи для них містяться в Законі України «Про забезпечення організаційно-правових умов соціального захисту дітей-сиріт та дітей, позбавлених батьківського піклування», порядок надання якої передбачений Постановою Кабінету Міністрів України від 31 січня 2007 р. № 81 «Про затвердження Порядку призначення і виплати державної соціальної допомоги на дітей-сиріт та дітей, позбавлених батьківського піклування, грошового забезпечення батькам-вихователям і прийомним батькам за надання соціальних послуг у дитячих будинках сімейного типу та прийомних сім'ях за принципом «гроші ходять за дитиною».

Що ж до соціального захисту дітей-інвалідів, то основним законом України, який регулює дане питання, є Закон «Про державну соціальну допомогу інвалідам 3 дитинства та дітям-інвалідам» [14], в якому містяться положення щодо категорій осіб, які мають право на державну соціальну допомогу, їі розміри, умови, порядок і строки виплати.

Закон України «Про соціальні послуги» [15] регулює питання надання соціальних послуг сім'ям 3 дітьми, багатодітним, неповним та малозабезпеченим сім'ям, дітям-сиротам та дітям, позбавленим батьківського піклування, інвалідам з дитинства та дітям-інвалідам, визначає види соціальних послуг, форми, порядок їх надання та умови іх отримання.

Правовою основою соціального захисту бездомних осіб і безпритульних дітей є Закон України «Про основи соціального захисту бездомних осіб і безпритульних дітей» [16], який містить основні принципи соціального захисту бездомних осіб і безпритульних дітей, їхні права та обов'язки, визначає заходи щодо запобігання бездомності і безпритульності.

Не менш важливим нормативно-правовим актом у системі національного законодавства у сфері соціального захисту сім'ї, дитинства, материнства та батьківства $€$ Закон України «Про соціальну роботу 3 сім'ями, дітьми та молоддю» [17], в якому визначаються основні принципи здійснення соціальної роботи з сім'ями, дітьми та молоддю, порядок та особливості її реалізації шляхом надання соціального обслуговування, здійснення соціальної профілактики серед сімей, дітей та молоді та їх соціальної реабілітації, також виокремлюються сфери та рівні здійснення такої соціальної роботи тощо.

Щодо підзаконних нормативно-правових актів - постанов Кабінету Міністрів України, указів Президента України, наказів різних відомств, то вони більше деталізують, уточнюють особливості, порядок, умови реалізації соціального захисту органами державної влади, громадськими, соціальними організаціями, сім'ями 3 дітьми, багатодітними, неповними та малозабезпеченими сім'ями, дітьми-сиротами та дітьми, позбавленими батьківського піклування, інвалідами 3 дитинства та дітьми-інвалідами. 


\section{Висновки}

Таким чином, проаналізувавши сучасний стан правового регулювання соціального захисту сім'ї, дитинства, материнства та батьківства в Україні, слід зауважити, що на нормативному рівні існує певна невпорядкованість відповідних видів соціального захисту сім'ї, дитинства, материнства та батьківства, оскільки норми, які визначають допомоги, послуги і пільги для сімей з дітьми, багатодітних, неповних та малозабезпечених сімей, дітей-сиріт та дітей, позбавлених батьківського піклування, інвалідів 3 дитинства та дітей-інвалідів та встановлюють соціальні гарантії реалізації їхнього права на соціальний захист, розосереджені в багатьох підзаконних нормативно-правових актах, що ускладнює застосування їх на практиці, а також призводить до незнання громадянами своїх соціальних прав. У зв'язку 3 цим пропонуємо систематизувати чинне законодавство у сфері соціального захисту сім'ї, дитинства, материнства та батьківства та прийняти єдиний нормативно-правовий акт, який би регулював дане питання.

\section{Список використаних джерел:}

1. Тищенко О.В.Державні соціальні стандарти та гарантії як основа соціального забезпечення в Україні. Юридичний вісник. 2013. № 4 (29). C. 99-104.

2. Алексеев С. С. Теория права. Москва : БЕК, 1994. $224 \mathrm{c}$

3. Комзюк А. Т. Заходи адміністративного примусу в правоохоронній діяльності міліції: поняття, види та організаційно-правові питання реалізації : монографія / за заг. ред. проф. О. М. Бандурки. Харків : Нац. ун-т внутр. справ, 2002. $336 \mathrm{c}$.

4. Болотіна Н. Б. Соціальне законодавство України. Гендерна експертиза / відп. ред. Т. М. Мельник. Київ : Логос, 2001. 82 с.

5. Конституція України: Науково-практичний коментар / ред. колегія В. Я. Тацій (голова редкол.) О. В. Петришин (відпов. секретар) Ю. Г. Бараш та ін.]; Нац. академ. прав. наук України. 2-ге вид., переробл. і доповн. Харків : Право, 2011. $112 \mathrm{c}$.

6. Сімейний кодекс України : Закон України від 10.01.2002 № 2947-III. URL: http:// zakon2.rada.gov.ua/laws/show/2947-14 (дата звернення: 02.12.2019).

7. Про освіту : Закон України від 05.09.2017 № 2145-VIII. URL: https://zakon.rada.gov.ua/laws/ show/2145-19 (дата звернення: 09.12.2019).

8. Про вищу освіту : Закон України від 01.07.2014 № 1556-VII. Відомості Верховної Ради України. 2014. № 37-38. Ст. 2004.

9. Про безоплатну правову допомогу : Закон України від 02.06.2011 № 3460-VI. Вiдомості Bepховної Ради України. 2011. № 51. Ст. 577.

10. Про державні соціальні стандарти та державні соціальні гарантії : Закон України від 05.10.2000 № 2017-III. Відомості Верховної Ради України. 2000. № 48. Ст. 409.

11. Про охорону дитинства : Закон України від 01.06.2000 № 1768-III. Відомості Верховної Ради України. 2001. № 30. Ст.142.

12. Про державну допомогу сім'ям 3 дітьми : Закон України від 21.11.1992 № 2811-XII. Відомості Верховної Ради Украӥни. 1993. № 5. Ст. 21.

13. Про державну соціальну допомогу малозабезпеченим сім'ям : Закон України» від 01.06.2000 № 1768-III. Відомості Верховної Ради України. 2000. № 35. Ст. 290.

14. Про державну соціальну допомогу інвалідам з дитинства та дітям-інвалідам : Закон України від 16.11.2000 № 2109-III. Відомості Верховної Ради України. 2001. № 1. Ст. 2.

15. Про соціальні послуги : Закон України від 19.06.2003 № 966-IV. Відомості Верховної Ради України. 2003. № 45. Ст. 358.

16. Про основи соціального захисту бездомних осіб і безпритульних дітей : Закон України від 02.06.2005 № 2623-IV. Відомості Верховної Ради України. 2005. № 26. Ст. 354 .

17. Про соціальну роботу з сім'ями, дітьми та молоддю : Закон України від 21.06.2001 № 2558-III. Відомості Верховної Ради України. 2001. № 42. Ст. 213.

In the article, based on the analysis of the norms of the current legislation, a description of the current state of legal regulation of social protection of family, childhood, motherhood and paternity in Ukraine is given. The problems of regulatory support of the outlined sphere are defined. It is proposed to systematize the current legislation in the field of social protection of the family, childhood, motherhood and paternity and to adopt a single legal act that would regulate this issue. It is determined that one of the main normative legal acts in the field of social protection of both the whole population and families with children, large children, incomplete and low-income families, orphans and children deprived of parental care, children with disabilities and children with disabilities is the Law Of Ukraine "On State Social Standards and State Social Guarantees", which establishes the most important state social standards and norms in various spheres of life. It is emphasized that state targeted support for higher education is: full or partial payment of tuition at the expense of state and local budgets; preferential long-term loans for education; social scholarships; free provision of textbooks; free access to the Internet, databases at state and municipal schools; free accommodation in the hostel; etc. It is concluded that at the regulatory level there is a certain disordering of the relevant types of social protection of the family, childhood, motherhood and paternity, since the rules governing benefits, services and benefits for families with children, large families, incomplete and needy families, orphans and children deprived of 
parental care, disabled children and disabled children and establish social guarantees for the exercise of their right to social protection, dispersed in many by-lawes, which complicates their application in practice, and also leads to ignorance of citizens of their social rights. In this regard, we propose to systematize the existing legislation in the field of social protection of the family, childhood, motherhood and paternity and to adopt a single legal act that would regulate this issue.

Key words: legal regulation, family social protection, childhood, motherhood, paternity, legislation. 